\title{
FACTORS OF OCCURRENCE OF OCULAR TOXOPLASMOSIS. A REVIEW ${ }^{1}$
}

\author{
TALABANI H.*, MERGEY T.*, YERA H.*, DELAIR E.**, \\ BRÉZIN A.P.**, LANGSLEY G.*** \& DUPOUY-CAMET J.*
}

\section{Summary:}

Acquired and congenital toxoplasmosis are frequently complicated by ocular toxoplasmosis. The diagnosis relies on clinical aspects, response to specific treatment and results of biological assays. The incidence and the prevalence of this complication are difficult to establish precisely and depend on the prevalence of the parasite infection in the general population, and are affected by factors such as type of exposure to the parasite, genetic backgrounds of the parasite and the host, and type of immune response elicited by the parasite.

KEY WORDS: toxoplasmosis, Toxoplasma, eye, retinochoroiditis.
Résumé : FACTEURS DE SURVENUE D'Une TOXOPLASMOSE OCULAIRE Les toxoplasmoses acquises ou congénitales sont fréquemment compliquées par des lésions oculaires. Le diagnostic de ces complications se fonde sur les aspects cliniques, la réponse au traitement spécifique et les résultats des analyses biologiques. L'incidence et la prévalence de ces complications sont difficiles à établir avec précision et dépendent de la prévalence de la parasitose dans la population générale et sont affectées par le type d'exposition au parasite, par la génétique de l'hôte et du parasite et par la réponse immune induite chez l'hôte par le parasite.

MOTS CLÉS : toxoplasmose, Toxoplasma, œil, choriorétinite.
$\mathrm{O}$ cular toxoplasmosis (OT) is a major cause of posterior uveitis worldwide. Diagnosis is usually based on ophthalmological examination and is confirmed by the response to specific treatment, but also by biological assays including local antibody production, PCR and Western Blot (RobertGangneux et al., 2004; Talabani et al., 2009; Villard et al., 2003). The incidence and the prevalence of this complication are difficult to establish precisely. In 1993, a survey in a French hospital service of ophthalmology showed that OT was seen in less than one per thousand outpatients (Dupouy-Camet et al., 1995). In another study performed in Germany, Jakob et al. (2009) reported that toxoplasmosis accounted for $4.2 \%$ of all cases of uveitis at their referral centre. Jones et al. (2010) estimated that 4,839 people develop symptomatic OT each year in the United States. Ocular toxoplasmosis is

\footnotetext{
* Service de Parasitologie-Mycologie.

** Service d'Ophtalmologie.

**** Laboratoire de Biologie Cellulaire Comparative des Apicomplexes, Departement de Maladies Infectieuses, Institut Cochin, Inserm, U567, Cnrs, UMR 8104, Hôpital Cochin, Assistance Publique-Hôpitaux de Paris, Université Paris Descartes, 27, rue du faubourg Saint Jacques, 75014 Paris, France.

Correspondence: Jean Dupouy-Camet, Department of ParasitologyMycology, Hôpital Cochin, 27, rue du faubourg Saint-Jacques, 75014 Paris, France.

E-mail: jean.dupouy-camet@cch.ap-hop-paris.fr

${ }^{1}$ This article is based on an oral presentation given at the international conference "Parasitic zoonoses in present day Europe", Belgrade, 18-20 November 2009.
}

a complication of both acquired acute and reactivated congenital toxoplasmosis (Delair et al., 2008; Holland, 1999; Stanford et al., 2006). Ocular disease severity can be influenced by variation in parasite isolates, parasitic load, route of infection and host-related factors such as immune function, age and pregnancy.

\section{FACTORS OF OCCURENCE OF OCULAR TOXOPLASMOSIS (OT)}

\section{OT COMPLICATES NOT ONLY CONGENITAL BUT ALSO ACQUIRED INFECTIONS}

C lassically, retinochoroiditis secondary to acquired toxoplasmosis was considered an exceptional event in immunocompetent individuals, and was usually defined as a periodic reactivation of latent cysts associated with undiagnosed congenital infections. But recent data, based on ophthalmological examination, seem to establish that acquired infection might be responsible for most cases. This fact was particularly demonstrated by outbreaks reported in Canada, Brazil or India. In Canada, amongst 100 individuals infected during a water-borne outbreak, 19 had OT (Bowie et al., 1997). In southern Brazil $17.7 \%$ of 1,042 individuals examined had OT. The prevalence of the lesions was $0.9 \%$ in 1 - to 8 -year-olds and $21.3 \%$ in all individuals older than 13 , suggesting that in this population, the 
disease was a sequela of postnatal rather than congenital infection (Glasner et al., 1992). In India, Balasundaram et al. (2010) described ocular involvement due to toxoplasmosis in 248 patients who had active retinochoroiditis and toxoplasmic serology suggesting recently acquired disease. Delair et al. (2008) analysed 425 cases of ocular toxoplasmosis, 100 (23.5\%) were acquired, $62(14.6 \%)$ were congenital, and $263(61.9 \%)$ were of unknown origin. At the time of the study, the mean age of the patients with congenital ocular toxoplasmosis was $9.1+/-8.8$ years, and $21.7+/-12.6$ years in the patients with the acquired disease $(\mathrm{p}<0.0001)$. In a recent study on clinical and serological data in the United Kingdom, Stanford et al. (2006) showed that $50 \%$ of OT in children was acquired after birth and that no clearclinical distinction could be made between acquired and congenital toxoplasmosis. However, other authors have identified specific clinical presentations to each group. Montoya et al. (1996) observed that patients with post-natal acquired toxoplasmic retinochoroiditis had mostly unilateral lesions without old scars or involvement of the macula. Delair et al. (2008) reported that bilateral OT was found in $4 \%$ of acquired cases and in $43.5 \%$ of congenital cases $(\mathrm{p}<0.0001)$ and that in acquired infections, visual acuity was significantly less impaired than in congenital infections. The risk of ocular disease depends on the trimester of pregnancy when infection occurred, and on whether or not treatment was administered to the mother during pregnancy. Kieffer et al. (2008) showed that a period exceeding eight weeks between maternal infection and the beginning of treatment, female gender, and especially cerebral calcifications were risk factors for retinochoroiditis. No significant association was found in other cohort studies between gestational age at maternal infection, prenatal treatment and the risk of developing OT (Binquet et al., 2003; Freeman et al., 2008).

\section{Host GENETIC BACKGROUND AND IMMUNE STATUS}

In mice, the virulence is linked to many factors related to either host immunity or the parasite, such as inoculum size, the infective stage (oocysts versus cysts), the route of infection and the genotype of the infecting strain. However, these data are not well documented in humans.

The acquired immune deficiency syndrome (AIDS) epidemic has dramatically reminded one that effective host immunity is essential to limit the severity of ocular lesions. AIDS patients without highly active antiretroviral therapy can develop extensive and recurring lesions (Holland et al., 1988). Similar lesions may also be encountered during the use of immunosuppressive therapy, or in the elderly (Montoya et al., 1996; Ronday et al., 1999). Many studies have focused on elderly patients (Holland, 2009; Johnson et al., 1997; Labalette et al.,
2002). These patients can have large and multiple ocular lesions with severe vitritis and prolonged disease, in some instances similar to lesions encountered in immunocompromised individuals, although they are otherwise healthy. Numerous changes occur in the immune system with advancing age, probably contributing to the higher severity of ocular toxoplasmosis in elderly patients. Indeed, both cellular and humoral immune responses are modified with advancing age (Johnson et al., 1997). A cross-sectional household study involving 499 individuals was undertaken in Minas Gerais state of Brazil, where infection with Toxoplasma gondii is endemic. The frequency of OT increased significantly with age, with approximately $50 \%$ of individuals $>60$ years of age having lesions (Portela et al., 2004). They also showed that older patients had a higher risk following recently acquired infection compared to younger patients.

The factors responsible for recurrences are unknown, but trauma, hormonal changes and cellular or humoral immunosuppression appear to contribute to the release of parasites from tissue cysts. Bosch-Driessen et al. (2002) reported an increased incidence of recurrences during pregnancy and after cataract surgery. The hormonal and immunological changes in pregnant women can cause recurrences and these authors described four women having such recurrences in every pregnancy. In a retrospective series, Kump et al. (2005) observed resistance to treatment and severe OT. Garweg et al. (2008) reported that recurrence occurred in approximately in four out of five patients and was higher two years after the first episode. Finally, a recent study confirmed that the risk of recurrence was the highest immediately after an episode of active disease and that recurrence had a tendency to occur in clusters (Holland et al., 2008).

Mice with different genetic backgrounds have different susceptibilities (Norose et al., 2003). In humans, an increased frequency of the HLA-Bw62 antigen was observed in patients with severe OT (Meenken et al., 1995). Jamieson et al. (2008) showed in mother-child pairs from Europe and North America that ocular disease in congenital toxoplasmosis was associated with polymorphisms in ABCA4 encoding ATP-binding cassette transporter and in a COL2A1 encoding type II collagen.

\section{SPECIFIC PARASITIC GENOTYPES ARE INVOLVED IN OT}

Currently, it is assumed that the population of T. gondii consists of three predominate clonal lineages, which differ at the DNA sequence level by $1 \%$ or less (Saeij et al., 2005). In Europe and the United States, type II is the most common cause of systemic Toxoplasma infection (Howe et al., 1997). The influence of the 
Toxoplasma genotype remains unclear, because of a low number of studied samples. Grigg et al. (2001) suggested a possible correlation between severe retinal disease and atypical genotypes in immunocompetent patients. Indeed, in acquired OT, an unusual abundance of type I, or recombinant genotypes I/III have been found in six immunocompetent patients in the USA. In Brazil, genetic studies have shown that genotypes of T. gondii involved in acquired OT were atypical, belonging to genotypes different from genotype II (Vallochi et al., 2005). Gilbert et al. (2008) highlighted severe ocular disease in congenitally infected Brazilian children compared with European children. The differences in the frequency, size and multiplicity of retinochoroidal lesions may be explained by more virulent parasite genotypes that predominate in Brazil, but are rarely found in Europe. Khan et al. (2006) compared 25 clinical and animal isolates of $T$. gondii from Brazil to previously characterised clonal lineages from North America and Europe. Genotypes of $T$. gondii strains isolated from Brazil were highly divergent when compared (by multilocus nested PCR analysis combined with sequencing of a polymorphic intron) to the previously described clonal lineages (e.g. genotype II) found in Europe. These atypical genotypes may also explain the high frequency (20\% of 97 cases) of ocular involvement in the above mentioned Canadian outbreak where an atypical cougar isolate was suspected, and the 100-fold higher incidence of OT in patients born in Africa compared to patients born in Britain (Burnett et al., 1998, Gilbert et al., 1995). The distribution of genotypes was different in immunocompromised patients who reactivate a type II strain (if acquired in Europe), or a non-type II strain (if acquired in Africa or South America). Grigg et al. (2001) reported various strains ( 2 types II, 1 type I, 1 types III and 1 atypical strain) from immunocompromised patients with OT.

\section{Pathogenesis of OT IS LinKed TO CYTOKINE RESPONSE}

Whereas the physiopathological mechanisms that underlie retinal damage in ocular toxoplasmosis are yet not fully understood, the immune response might directly affect the pathogenesis of toxoplasmic retinochoroiditis and some cytokines have been shown to be fundamental to either control or block a protective response against $T$. gondii in experimental models. In animal experiments, many authors have described that IFN $\gamma$ and TNF $\alpha$, which enhance macrophage activation and induce production of other cytokines such as IL-12, give rise to a type Th1 immune response that plays a crucial role in parasite control (Jones et al., 2006). These two cytokines could play a major role in immunological responses that control parasite proliferation by induction of indoleamine 2,3-dioxygenase production in retinal pigment epithelial cells (Nagineni et al., 1996). Moreover, Gazzinelli et al. observed that compared to control animals, mice treated with IFN $\gamma$ or TNF $\alpha$ antagonists or antibodies against $\mathrm{T}$ cells (CD4 and CD8), showed more severe lesions characterized by exacerbated ocular damage and increased parasite detection in the eye. Conversely, deviation to a Th2 immune response with production of anti-inflammatory cytokines including IL-10, TGF- $\beta$ and IL- 4 could promote parasite survival, but is required to maintain immune privilege in the eye and prevent immune destruction of tissue (Gaddi et al., 2007).

In man, the participation of inflammatory mediators in physiopathology of OT is not yet clear. Nevertheless, a study by Yamamoto et al. (2000) showed that asymptomatic patients secreted significantly more IL-12 and IFN $\gamma$ in response to Toxoplasma antigens than patients with ocular damage. Conversely, acquired OT was associated with high levels of IL-1 and TNF $\alpha$. They also observed that in comparison with non-infected subjects, IL-2 and IFN $\gamma$ production by peripheral blood mononuclear cells in response to T. gondii was decreased for subjects with congenital infection, suggesting a status of parasite tolerance. Ongkosuwito et al. (1998) measured the levels of six chemokines directly in aqueous humor samples from patients presenting viral or toxoplasmic uveitis. Interestingly, IL-6 titers in patients with OT correlated with the degree of activity of toxoplasmic chorioretinitis. This cytokine is now described as essential in Th17 differentiation and Th17 cells are involved in inflammatory and autoimmune uveitis, supporting the hypothesis that host immune response could take part in ocular damages (Yoshimura et al., 2009).

The expansion of IL-17 producing cells in human OT has been demonstrated by Lahmar et al. (2009) who monitored cytokine patterns in serum and aqueous humor of subjects suffering from OT, infectious or noninfectious uveitis and cataract. High levels of IL-17 were reported in aqueous humor samples from $70 \%$ patients presenting OT. This aspect was shared with another group suffering from eye inflammatory disease, showing that inflammatory processes could play a major role in the establishment of ocular damage in the chronic stage of OT. Due to large inter-individual variations of cytokine levels within each group of patients, no correlation was found between cytokine titers and clinical presentation (Lahmar et al., 2009). In addition, increased levels of proinflammatory mediators MCP-1, IL- 8 and IL- 6 were found in intraocular fluid samples from OT, but these variations were not specific for toxoplasmic uveitis. IL-12 can enhance TNF production and synthesis was higher in OT than in other ocular diseases in accordance with the importance of the Th1 response in mouse models. The Th2 cytokines (Il-4, IL-5, IL-10), which counterbalance inflammatory processes, were up-regulated and 
consequently the authors were unable to define the respective roles of Th1 and Th2 responses in the pathogenesis of human OT (Lahmar et al., 2009). As observed in experimental autoimmune uveitis, it is now proposed that eye damage may be induced by pathogenic responses mediated by Th-17 cells producing TNF $\alpha$ (Garweg et al., 2009). Conversely, host hypersensitivity pathways in the eye might be counterbalanced by IL-27 secretion up-regulated by IFN $\gamma$ from Th1 cells (Garweg et al., 2009). Finally, Cordeiro et al. (2008a, b, c) and Albuquerque et al. (2009) investigated a possible association between polymorphisms in cytokine genes and OT in human patients. They showed that an IL-10 $(-1082 \mathrm{G} / \mathrm{A})$ and an IFN $\gamma(+874 \mathrm{~T} / \mathrm{A})$ allele were preferentially found in patients with OT. No such association was found with TNF $\alpha$ gene polymorphisms. They also showed that such a polymorphism decreasing IL-1 production $(-889 \mathrm{C} / \mathrm{T})$ was associated with recurrent OT.

\section{CONCLUSIONS}

A cquired or congenital toxoplasmosis can be complicated by ocular toxoplasmosis. The diagnosis relies on clinical aspects, responses to specific treatment and results of biological assays. The incidence and the prevalence of this complication are both difficult to establish precisely and depend on the parasite prevalence in the general population, and are affected by different factors such as type of exposure to the parasite, genetic background of the different parasites and the host, and the type of immune response elicited by the parasite. Prevention of congenital toxoplasmosis and a rapid specific treatment of acquired cases are the key measures to avoid severe visual impairment.

\section{ACKNOWLEDGEMENTS}

any thanks to Prof. E. Candolfi (Strasbourg)
for his excellent suggestions.

\section{REFERENCES}

Albuquerque M.C., Aleixo A.L., Benchimol E.I., Leandro A.C., Das Neves L.B., Vicente R.T., Bonecini-Almeida Mda G. \& AmendoeIRA M.R. The IFN-gamma +874 T/A gene polymorphism is associated with retinochoroiditis toxoplasmosis susceptibility. Mem. Inst. Oswaldo Cruz, 2009, 104, 451-455.

Balasundaram M.B., Andavar R., Palaniswamy M. \& VenkataPATHY N. Outbreak of acquired ocular toxoplasmosis involving 248 patients. Arch. Ophthalmol., 2010, 128, 28-32.
Binquet C., Wallon M., Quantin C., Kodjikian L., Garweg J., Fleury J., Peyron F. \& Abrahamowicz M. Prognostic factors for the long-term development of ocular lesions in 327 children with congenital toxoplasmosis. Epidemiol. Infect., 2003, 131, 1157-1168.

Bosch-Driessen L.E., Berendschot T.T., Ongkosuwito J.V. \& RoTHOvA A. Ocular toxoplasmosis: clinical features and prognosis of 154 patients. Ophthalmology, 2002, 109, 869-878.

Bowie W.R., King A.S., Werker D.H., Isaac-Renton J.L., Bell A., ENG S.B. \& MARION S.A. Outbreak of toxoplasmosis associated with municipal drinking water. The BC Toxoplasma Investigation Team. Lancet, 1997, 350, 173-177.

Burnett A.J., Shortt S.G., Isaac-Renton J., King A., Werker D. \& BowIE W.R. Multiple cases of acquired toxoplasmosis retinitis presenting in an outbreak. Ophthalmology, 1998, 105, 1032-1037.

Cordeiro C.A., Moreira P.R., Andrade M.S., Dutra W.O., CAmpos W.R. , Orefice F. \& TeIXEIRA A.L.. Interleukin-10 gene polymorphism $(-1082 \mathrm{G} / \mathrm{A})$ is associated with toxoplasmic retinochoroiditis. Invest. Ophthalmol. Vis. Sci., 2008a, 49, 1979-1982.

Cordeiro C.A., Moreira P.R., Costa G.C., Dutra W.O., Campos W.R., Orefice F. \& Teixeira A.L. Interleukin-1 gene polymorphisms and toxoplasmic retinochoroiditis. Mol. Vis., 2008b, 14, 1845-1849.

Cordeiro C.A., Moreira P.R., Costa G.C., Dutra W.O., Campos W.R., OREFICE F. \& TEIXEIRA A.L. TNF-alpha gene polymorphism (-308G/A) and toxoplasmic retinochoroiditis. Br.J. Ophthalmol., 2008c, 92, 986-988.

Delair E., Monnet D., Grabar S., Dupouy-Camet J., Yera H. \& BREZIN A.P. Respective roles of acquired and congenital infections in presumed ocular toxoplasmosis. Am. J. Ophthalmol., 2008, 146, 851-855.

Dupouy-Camet J., Lahmi T., Vidal-Trecan G., Ancelle T. \& Mondon H. Prévalence des choriorétinites toxoplasmiques chez 4019 consultants d'un service d'ophtalmologie. Bulletin Épidémiologique Hebdomadaire, 1995, 2, 27.

Freeman K., Tan H.K., Prusa A., Petersen E., Buffolano W., Malm G., Cortina-Borja M. \& Gilbert R. Predictors of retinochoroiditis in children with congenital toxoplasmosis: European, prospective cohort study. Pediatrics, 2008, 121, e1215-22.

GADDI P.J. \& YAP G.S. Cytokine regulation of immunopathology in toxoplasmosis. Immunol. Cell. Biol., 2007, 85, 155-159.

GARWEG J.G. \& CANDOLFI E. Immunopathology in ocular toxoplasmosis: facts and clues. Mem. Inst. Oswaldo Cruz, 2009, $104,211-220$

Garweg J.G., Scherrer J.N. \& Halberstadt M. Recurrence characteristics in European patients with ocular toxoplasmosis. Br.J. Ophthalmol., 2008, 92, 1253-1256.

Gazzinelui R.T., Brezin A., Li Q., Nussenblatt R.B. \& Chan C.C. Toxoplasma gondii: acquired ocular toxoplasmosis in the murine model, protective role of TNF-alpha and IFNgamma. Exp. Parasitol., 1994, 78, 217-229.

Gilbert R.E., Freeman K., Lago E.G., Bahia-Oliveira L.M., Tan H.K., Wallon M., Buffolano W., Stanford M.R. \& Petersen E. 
Ocular sequelae of congenital toxoplasmosis in Brazil compared with Europe. PLoS Negl. Trop. Dis., 2008, 2, e277.

Gilbert R.E., Stanford M.R., Jackson H., Holliman R.E. \& SANDERS M.D. Incidence of acute symptomatic toxoplasma retinochoroiditis in south London according to country of birth. BMJ, 1995, 310, 1037-1040.

Glasner P.D., Silveira C., Kruszon-Moran D., Martins M.C., Burnier M. Jr, Silveira S., Camargo M.E., Nussenblatt R.B., KASLOW R.A. \& BELFORT R. Jr. An unusually high prevalence of ocular toxoplasmosis in southern Brazil. Am. J. Ophthalmol., 1992, 114, 136-144.

Grigg M.E., Ganatra J., Boothroyd J.C. \& Margolis T.P. Unusual abundance of atypical strains associated with human ocular toxoplasmosis. J. Infect. Dis., 2001, 184, 633-639.

Holland G.N. Ocular toxoplasmosis: the influence of patient age. Mem. Inst. Oswaldo Cruz., 2009, 104, 351-357.

Holland G.N. Reconsidering the pathogenesis of ocular toxoplasmosis. Am. J. Ophthalmol., 1999, 128, 502-505.

Holland G.N., Crespi C.M., Ten Dam-Van Loon N., Charonis A.C., Yu F., Bosch-Driessen L.H. \& Rothova A. Analysis of recurrence patterns associated with toxoplasmic retinochoroiditis. Am.J. Ophthalmol., 2008, 145, 1007-1013.

Holland G.N., Engstrom R.E. Jr., Glasgow B.J., Berger B.B., Daniels S.A., Sidikaro Y., Harmon J.A., Fischer D.H., Boyer D.S., RAO N.A. et al. Ocular toxoplasmosis in patients with the acquired immunodeficiency syndrome. Am. J. Ophthalmol., 1988, 106, 653-667.

Howe D.K., Honore S., Derouin F. \& Sibley L.D. Determination of genotypes of Toxoplasma gondii strains isolated from patients with toxoplasmosis. J. Clin. Microbiol., 1997, 35, 1411-1414.

Jakob E., Reuland M.S., Mackensen F., Harsch N., Fleckenstein M., Lorenz H.M., MAX R. \& BeCKer M.D. Uveitis subtypes in a german interdisciplinary uveitis center-analysis of 1916 patients. J. Rheumatol., 2009, 36, 127-136.

Jamieson S.E., De Roubaix L.A., Cortina-Borja M., Tan H.K., Mui E.J., Cordell H.J., Kirisits M.J., Miller E.N., Peacock C.S., Hargrave A.C., Coyne J.J., Boyer K., Bessieres M.H., Buffolano W., Ferret N., Franck J., Kieffer F., Meier P., Nowakowska D.E., Paul M., Peyron F., Stray-Pedersen B., Prusa A.R., Thulliez P., Wallon M., Petersen E., Mcleod R., Gilbert R.E. \& BlackWELl J.M. Genetic and epigenetic factors at COL2A1 and ABCA4 influence clinical outcome in congenital toxoplasmosis. PLoS One, 2008, 3, e2285.

Johnson M.W., Greven G.M., Jaffe G.J., Sudhalkar H. \& VINE A.K. Atypical, severe toxoplasmic retinochoroiditis in elderly patients. Ophthalmology, 1997, 104, 48-57.

JONES J.L. \& HolLAND G.N. Annual burden of ocular toxoplasmosis in the US. Am. J. Trop. Med. Hyg., 2010, 82, 464-546.

Jones L.A., AleXANDER J. \& RoBerTs C.W. Ocular toxoplasmosis: in the storm of the eye. Parasite Immunol., 2006, 28, 635-642.

Khan A., Jordan C., Muccioli C., Vallochi A.L., Rizzo L.V., Belfort R. JR, Vitor R.W., Silveira C. \& Sibley L.D. Genetic divergence of Toxoplasma gondii strains associated with ocular toxoplasmosis, Brazil. Emerg. Infect. Dis., 2006, 12, 942-949.
Kieffer F., Wallon M., Garcia P., Thulliez P., Peyron F. \& FRANCK J. Risk factors for retinochoroiditis during the first two years of life in infants with treated congenital toxoplasmosis. Pediatr. Infect. Dis. J., 2008, 27, 27-32.

Kump L.I., ANDROUdi S.N. \& Foster C.S. Ocular toxoplasmosis in pregnancy. Clin. Experiment. Ophthalmol., 2005, 33, 455-460.

Labalette P., Delhaes L., Margaron F., Fortier B. \& Rouland J.F. Ocular toxoplasmosis after the fifth decade. Am. J. Ophthalmol., 2002, 133, 506-515.

Lahmar I., Abou-Bacar A., Abdelrahman T., Guinard M., BabBa H., Ben Yahia S., Kairallah M., Speeg-Schatz C., Bourcier T., Sauer A., Villard O., Pfaff A.W., Mousli M., Garweg J.G. \& Candolfi E. Cytokine profiles in toxoplasmic and viral uveitis. J. Infect. Dis., 2009, 199, 1239-1249.

Meenken C., Rothova A., De Waal L.P., Van Der Horst A.R., Mesman B.J. \& KiJlstra A. HLA typing in congenital toxoplasmosis. Br. J. Ophthalmol., 1995, 79, 494-497.

Montoya J.G. \& Remington J.S. Toxoplasmic chorioretinitis in the setting of acute acquired toxoplasmosis. Clin. Infect. Dis., 1996, 23, 277-282.

Nagineni C.N., Pardhasaradhi K., Martins M.C., Detrick B. \& Hooks J.J. Mechanisms of interferon-induced inhibition of Toxoplasma gondii replication in human retinal pigment epithelial cells. Infect. Immun., 1996, 64, 4188-4196.

Norose K., Mun H.S., Aosai F., Chen M., Piao L.X., Kobayashi M., IWAKURA Y. \& YANO A. IFN-gamma-regulated Toxoplasma gondii distribution and load in the murine eye. Invest. Ophthalmol. Vis. Sci., 2003, 44, 4375-4381.

Ongkosuwito J.V., Feron E.J., Van Doornik C.E., Van Der Lelij A., Hoyng C.B., La Heij E.C. \& Kijlstra A. Analysis of immunoregulatory cytokines in ocular fluid samples from patients with uveitis. Invest. Ophthalmol. Vis. Sci., 1998, 39, 2659-2665.

Portela R.W., Bethony J., Costa M.I., Gazzinelli A., Vitor R.W., Hermeto F.M., Correa-Oliveira R. \& Gazzinelli R.T. A multihousehold study reveals a positive correlation between age, severity of ocular toxoplasmosis, and levels of glycoinositolphospholipid-specific immunoglobulin A. J. Infect. Dis., 2004, 190, 175-183.

Robert-Gangneux F., Binisti P., Antonetti D., Brezin A., Yera H. \& DuPOUY-CAMET J. Usefulness of immunoblotting and Goldmann-Witmer coefficient for biological diagnosis of toxoplasmic retinochoroiditis. Eur.J. Clin. Microbiol. Infect. Dis., 2004, 23, 34-38.

Ronday M.J., Ongkosuwito J.V., Rothova A. \& Kijlstra A. Intraocular anti-Toxoplasma gondii IgA antibody production in patients with ocular toxoplasmosis. Am. J. Ophthalmol., 1999, 127, 294-300.

SAeij J.P., Boyle J.P. \& Boothroyd J.C. Differences among the three major strains of Toxoplasma gondii and their specific interactions with the infected host. Trends Parasitol., 2005, 21, 476-481.

STANFORD M.R., TAN H.K. \& GilberT R.E. Toxoplasmic retinochoroiditis presenting in childhood: clinical findings in a UK survey. Br.J. Ophthalmol., 2006, 90, 1464-1467.

Talabani H., Asseraf M., Yera H., Delair E., Ancelle T., Thulliez P., Brezin A.P. \& Dupouy-Camet J. Contributions of 
immunoblotting, real-time PCR, and the Goldmann-Witmer coefficient to diagnosis of atypical toxoplasmic retinochoroiditis. J. Clin. Microbiol., 2009, 47, 2131-2135.

Vallochi A.L., Muccioli C., Martins M.C., Silveira C., Belfort R. JR \& Rizzo L.V. The genotype of Toxoplasma gondii strains causing ocular toxoplasmosis in humans in Brazil. Am.J. Ophthalmol., 2005, 139, 350-351.

Villard O., Filisetti D., Roch-Deries F., Garweg J., Flament J. \& CANDOlfi E. Comparison of enzyme-linked immunosorbent assay, immunoblotting, and PCR for diagnosis of toxoplasmic chorioretinitis. J. Clin. Microbiol., 2003, 41, 3537-3541.

Yamamoto J.H., Vallochi A.L., Silveira C., Filho J.K, NussenBlatt R.B., Cunha-Neto E., Gazzinelli R.T., Belfort R. JR. \& Rizzo L.V. Discrimination between patients with acquired toxoplasmosis and congenital toxoplasmosis on the basis of the immune response to parasite antigens. J. Infect. Dis., 2000, 181, 2018-2022.

Yoshimura T., Sonoda K.H., Ohguro N., Ohsugi Y., Ishibashi T., Cua D.J., Kobayashi T., Yoshida H. \& Yoshimura A. Involvement of Th17 cells and the effect of anti-IL-6 therapy in autoimmune uveitis. Rheumatology (Oxford), 2009, 48, 347-354.

Reçu le 14 mai 2010 Accepté le 17 juin 2010 